Among the livestock of India, goats have fulfilled agricultural, economic, cultural and even religious roles from very early times in human civilization. They are the most

\section{Haemato-Biochemical Profile of Black Bengal Goat on Different Gastro-Intestinal Parasitic Load}

\author{
K. C. Dhara ${ }^{1}$, N. Ray ${ }^{1}$, S. S. Kesh ${ }^{2 *}$, P. K. Bandopadhyay ${ }^{3}$, S. Batabyal ${ }^{4}$ and A. Goswami ${ }^{4}$ \\ ${ }^{1}$ Department of Zoology, University of Kalyani, West Bengal University of Animal \& Fishery \\ Sciences, Kolkata-700037, West Bengal, India \\ ${ }^{2}$ Department of Veterinary Clinical Complex (Vety. Biochemistry), West Bengal University of \\ Animal \& Fishery Sciences, Kolkata-700037, West Bengal, India \\ ${ }^{3}$ Departments of Zoology, University of Kalyani, West Bengal, India \\ ${ }^{4}$ West Bengal University of Animal \& Fish Sciences, Kolkata-700037, West Bengal, India
}

*Corresponding author

\section{A B S T R A C T}

\begin{tabular}{|l|}
\hline Ke y w o r d s \\
Blood sample, \\
Black Bengal, \\
Genetic resources \\
\hline Article Info \\
\hline Accepted: \\
12 March 2020 \\
Available Online: \\
10 April 2020 \\
\hline
\end{tabular}

\section{Introduction}

A study was conducted of a total of one thousand four hundred sixteen blood samples collected from one hundred eighteen Black Bengal does in every months during July, 2004 to June, 2005 to assesses haemato biochemical profile of black Bengal goat in accordance to the level of gastrointestinal nematodes as a good indicator of parasitic load to take decision for selection of goat to conserve the genetic resources with their up gradation for better production and supply of healthy, disease free products for human use. In this aspect, the present study was conducted with the objective to assess the haematobiochemical profile of Black Bengal goat. The does of base stock having EPG count more than 1200 (Group 3) showed anaemia and erythrocytopenia with significant decrease in PCV and TEC and hypoproteinaemia with reduction in TSP and SA. The Group 3 animals also showed significant increase in alkaline phosphatase and AST activity. Though the affected goats do not show clinical illness but EPG count more than 1200 can lead to anaemia, erythrocytopenia, hypoproteinaemia and increased activity of serum AST and alkaline phosphatase enzymes give birth to inferior progenies generation after generation and the progenies are also susceptible to infection while benefit can be obtained by rearing goats of low EPG count along with corresponding high PCV, Hb and TSP value perform better generation after generation.

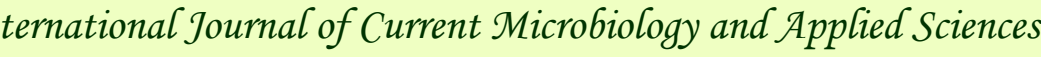

Corresponding author

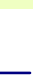


Goats make an important contribution to the sustenance of small and marginal landholders and landless rural people by their contribution towards marketable commodities such as meat, milk, fibre and skin. It also plays a leading role in eradication of poverty in small farmers and landless labourers by selfemployment and thus improvement of goat production is necessary to benefit the rural community. (Dhara et al., 2011)Though most of the Indian breeds of goats are well adapted to the harsh environment, low nutrition, tropical disease and poor water quality, gastrointestinal parasites are considered to one of the top ten ranked disease in goats (Rout and Chauhan, 2004).

In the world when goat producers are facing increasing problems due to the rapid spread of antihelmintic resistance, the battle against gastrointestinal nematodes is a difficult one. Widespread infection with internal parasites in grazing animals, associated production losses, antihelmintic costs and death of infected animals are some of the major concerns. India is paradise of many parasites due to its hot and humid climatic condition. The climatic factor may favour the development of gastro-intestinal parasites during the period of nutritional stress and wet season in the tropical area (Hawlader et al., 2002) like India. The most important helminthes infections of livestock are infections of grazing ruminants by nematodes residing within the gastrointestinal (GI) tract of the vertebrate host.

Strongyle infestation significantly affects the body weight gain of sheep and goat and this reflects in haemato biochemical profile of the animal which ultimately a good indicator of parasitic load to take decision for selection goat to conserve the genetic resources with their up gradation for better production and supply of healthy, disease free products for human use. In this aspect, the present study was conducted with the objective to assess the haemato- biochemical profile of Black Bengal goat in accordance to the level of gastrointestinal nematodes

\section{Materials and Methods}

The study was conducted at Mohanpur village under Haringhata block in the Nadia district of West Bengal state which is under New Alluvial zone of Lower Gangetic Plain region of India with a total of one hundred eighteen Black Bengal does with age of three months and above. All the one hundred eighteen does were divided into three groups depending upon the mean annual egg per gram of faeces (EPG) count of gastrointestinal nematode, Strongyle sp. from July 2004 to June 2005 and they were considered as base stock. The groups were - Group 1 (Low EPG < 600), Group 2 (Moderate EPG >600< 1200) and Group 3 (High EPG > 1200).

All the animals utilized for the present study were maintained in the farmers' house with almost uniform management practice. All the animals were dewormed four times in a year. Deworming was performed on the basis of faecal examination. Vaccination against PPR, Goat pox and FMD was done in every year. A part of individual faecal samples were subjected to direct microscopic examination as well as floatation and sedimentation methods (Soulsby, 1982) for prevalence study of gastrointestinal parasites. All the positive samples were subjected to eggs per gram of faeces (EPG) count for strongyle group of gastrointestinal nematodes, by employing modified McMaster technique (Coles et al., 1992).

\section{Collection of blood}

Blood were collected from a total of one hundred eighteen does in each month during the year July, 2004 to June, 2005. Eight 
millimeter of blood was drawn out by jugular vein puncture of the goats using standard aseptic procedure after proper marking with animal number.

Out of $8 \mathrm{ml}$ of blood drawn, $3 \mathrm{ml}$ was taken in a sterilized screw capped vial containing the required amount of EDTA @ $1 \mathrm{mg} / \mathrm{ml}$ of the blood as anticoagulant. Out of $8 \mathrm{ml}$ blood drawn, $5 \mathrm{ml}$ of blood (without anticoagulant) was kept undisturbed for two to three hours in same syringe to clot for separation of serum.

The serum was taken in a sterilized screwcapped vial and stored at $-20^{\circ} \mathrm{C}$ in a deep freezer after proper marking with animal number till further use. The enzyme activities were estimated within forty eight hours of collection, whereas the other biochemical parameters were estimated within a week after collection.

\section{Haematological estimation}

\section{Haemoglobin (Hb)}

Hemoglobin was estimated by Sahli's method as described by Schalm et al., (1986). The result was expressed in gram per deciliter (g/dl) of blood.

\section{Packed cell volume (PCV)}

PCV of the blood samples were estimated in Wintrobe's haematocrit tube and reading were taken after centrifuging blood at the rate of three thousand r.p.m. for thirty minutes as per standard method of Schalm et al., (1986) and were expressed in percentage $(\%)$ of total volume.

\section{Total erythrocyte count (TEC)}

TEC was estimated by using haemocytometre as described by Schalm et al., (1986). RBC was differentiated by the characteristic shape and intensity of stain taken. The result of TEC was expressed as millions per cubic millimeter (106/cu.mm).

\section{Total leukocyte count (TLC)}

TLC was estimated by using haemocytometre as described by Schalm et al., (1986). WBC was differentiated by the characteristic shape and intensity of stain taken. The result of TLC was expressed as thousand per cubic millimeter (103/cu.mm).

\section{Differential leukocyte count (DLC)}

DLC was performed following the method described by Schalm et al., (1986).

\section{Serum biochemical estimation}

\section{Total serum protein (TSP)}

TSP was estimated spectrophotometrically by Biuret method (Reinhold, 1953) using the diagnostic reagent kit (SPAN, Code No. B0211) and the values were expressed in gram per deciliter (g/dl).

Serum albumin (SA), serum globulin (SG) and albumin and globulin ratio (SA: SG)

Serum albumin was determined spectrophotometrically by the method described by Dumas et al., (1971). The value of serum globulin was estimated by subtracting the value of SA from that of TSP. The value of SA and SG were expressed in gram per deciliter (g/dl).

\section{Aspertate aminotransferase (AST)}

Serum AST was estimated spectrophotometrically by 2, 4-DNPH method (Reitman and Frankel, 1957) using the diagnostic reagent kit (SPAN, Code No. 25913) and result was expressed in IU/L of serum. 


\section{Alanine aminotransferase (ALT)}

Serum ALT was estimated spectrophotometrically by 2, 4-DNPH method (Reitman and Frankel, 1957) using the diagnostic reagent kit (SPAN, Code No. 25912) and result was expressed in IU/L of serum.

\section{Serum alkaline phosphatase}

Serum alkaline phosphatase was estimated spectrophotometrically by Kind and Kings method (Kind and King, 1954) using the diagnostic reagent kit (SPAN, Code No. 25904) and result was expressed in IU/L of serum.

\section{Statistical methodology}

The effect of the intensity of GI nematode infection (EPG) of the base stock on the haemato biochemical profile was estimated by analysis of variance (Snedecor and Cochran, 1994). The formulae used for statistical analysis were:

$\mathrm{Yijk}=\mu+\mathrm{Ai}+\mathrm{eik}$

Where:

Yik $=$ kth animal of the ith EPG group $\mu \quad=\quad$ overall mean

$\mathrm{Ai}=$ Effect of EPG ( $\mathrm{j}=1$ to 3 )

eik $=$ Random error on observation distributed NID $(0, \sigma 2 \mathrm{e})$

From the above model, it was calculated $\mathrm{CF}=$ Grand Total (GT) ${ }^{2} / \mathrm{N}$ (Number) Sum Squire (SSA) (Between EPG group) $=\sum$ Ai2

Sum Squire $(\mathrm{SST})($ Total $)=\sum$ Yik2 $-\mathrm{CF}$ Sum Squire $(\mathrm{SSe})$ (error) $=\mathrm{SST}-\mathrm{SSA}$

The critical difference test (CD test) was carried out for the traits, which showed significant differences. This is done to compare between the means of sub-classes by applying the following formula.

$|\mathrm{B} 1-\mathrm{B} 2|>\mathrm{t} 1 / 2 \alpha(\mathrm{N}-5) \mathrm{X} \sqrt{\mathrm{MSe}}($ Mean sum square error) $(1 / \mathrm{N} 1+1 / \mathrm{N} 2)$

\section{Results and Discussion}

\section{Haemato-biochemical study}

The haemato-biochemical values of a total of one thousand four hundred sixteen blood samples collected from one hundred eighteen Black Bengal does in every months during July, 2004 to June, 2005 were estimated and the results were analyzed in accordance with the level of EPG.

\section{Haematological study}

The result of haematocrit values has been presented in Table 11 and analysis of variance has been presented in Table 12. The result of haemoglobin concentration revealed a gradual decrease in $\mathrm{Hb}$ percentage from Group 1 to Group 3 (10.15\%, 9.94\% and 9.03\% respectively). The $\mathrm{Hb}$ concentration of Group 3 was statistically significant $(\mathrm{P}<0.01)$ from both Group 1 and Group 2. The difference between Group 1 and Group 2 was nonsignificant. The statistical analysis of PCV (\%) and TEC (106cumm) values showed that the decrease in PCV and TEC of Group 3 $(24.96 \%$ and $10.25 \mathrm{X}$ 106cumm) were significant $(\mathrm{P}<0.01)$ in comparison to Group 1 (28.85\% and 12.62 X106cumm) and Group 2 (28.04\% and $12.45 \mathrm{X} 106 \mathrm{cumm})$.

It was further evident that changes in the values of TLC did not follow a consistent trend and the variation among Group 1 (9.78 x 103cumm), Group 2 (9.86 x 103cumm) and Group 3 (9.56 x 103cumm) were nonsignificant. The statistical analysis of DLC values revealed non- significant changes in the individual cells between the three groups. 
Table.1 Haematological values of Black Bengal goat in different level of EPG count $($ Mean \pm SEM)

\begin{tabular}{|c|c|c|c|c|c|c|c|c|c|}
\hline \multirow[t]{2}{*}{ Groups } & \multirow{2}{*}{$\begin{array}{c}\text { Hb } \\
\text { (g/dl) }\end{array}$} & \multirow{2}{*}{$\begin{array}{r}\text { PCV } \\
(\%)\end{array}$} & \multirow{2}{*}{$\begin{array}{c}\text { TEC } \\
(\mathbf{1 0} \% \text { cu.mm) }\end{array}$} & \multirow{2}{*}{$\begin{array}{c}\text { TLC } \\
\left(10^{3} / \text { cu.mm }\right)\end{array}$} & \multicolumn{5}{|c|}{$\operatorname{DLC}(\%)$} \\
\hline & & & & & $\begin{array}{c}\text { Lymph } \\
(\%)\end{array}$ & $\begin{array}{l}\mathrm{Ne} \\
(\%)\end{array}$ & $\begin{array}{c}\text { Eo } \\
(\%)\end{array}$ & $\begin{array}{c}\text { Baso } \\
(\%)\end{array}$ & $\begin{array}{c}\text { Mono } \\
(\%)\end{array}$ \\
\hline $\begin{array}{l}\text { Group-1 } \\
(N=49)\end{array}$ & $\begin{array}{c}10.15 \\
\pm 0.10^{\text {a }}\end{array}$ & $\begin{array}{c}28.85 \\
\pm 0.44^{\text {a }}\end{array}$ & $\begin{array}{c}12.62 \\
\pm 0.13^{\mathrm{a}}\end{array}$ & $\begin{array}{c}9.78 \\
\pm 0.15\end{array}$ & $\begin{array}{c}58.73 \\
\pm 0.61\end{array}$ & $\begin{array}{c}38.55 \\
\pm 0.58\end{array}$ & $\begin{array}{c}2.06 \\
\pm 0.11\end{array}$ & $\begin{array}{c}0.16 \\
\pm 0.05\end{array}$ & $\begin{array}{r}0.49 \\
\pm 0.09\end{array}$ \\
\hline $\begin{array}{c}\text { Group-2 } \\
(N=58)\end{array}$ & $\begin{array}{c}9.94 \\
\pm 0.09^{\mathrm{a}}\end{array}$ & $\begin{array}{c}28.04 \\
\pm 0.38^{\mathrm{a}}\end{array}$ & $\begin{array}{c}12.45 \\
\pm 0.11^{\mathrm{a}}\end{array}$ & $\begin{array}{c}9.86 \\
\pm 0.13\end{array}$ & $\begin{array}{l}57.79 \\
\pm 0.48\end{array}$ & $\begin{array}{l}39.28 \\
\pm 0.45\end{array}$ & $\begin{array}{c}2.17 \\
\pm 0.13\end{array}$ & $\begin{array}{c}0.26 \\
\pm 0.06\end{array}$ & $\begin{array}{r}0.50 \\
\pm 0.07\end{array}$ \\
\hline $\begin{array}{c}\text { Group-3 } \\
(\mathbf{N}=11)\end{array}$ & $\begin{array}{c}9.03 \\
\pm 0.14^{\mathrm{b}}\end{array}$ & $\begin{array}{c}24.96 \\
\pm 0.34^{\mathrm{b}}\end{array}$ & $\begin{array}{c}10.25 \\
\pm 0.34^{\mathrm{b}}\end{array}$ & $\begin{array}{c}9.56 \\
\pm 0.20\end{array}$ & $\begin{array}{l}57.91 \\
\pm 1.37\end{array}$ & $\begin{array}{r}39.09 \\
\pm 1.39\end{array}$ & $\begin{array}{c}2.36 \\
\pm 0.15\end{array}$ & $\begin{array}{c}0.18 \\
\pm 0.12\end{array}$ & $\begin{array}{r}0.45 \\
\pm 0.16\end{array}$ \\
\hline F Value & $11.74 * *$ & $8.39 * *$ & $32.06^{* *}$ & 0.42 & 0.77 & 0.49 & 0.64 & 0.75 & 0.03 \\
\hline
\end{tabular}

Values bearing same or no superscript within a column do not differ significantly $(\mathrm{P}<0.01)$.

$* \mathrm{P}<0.05 \quad * * \mathrm{P}<0.01$

\section{Serum biochemical study}

The result of total serum protein (TSP), albumin (SA), globulin (SG) and SA : SG ratio and the statistical analysis of variances have been presented in Table 13 and Table 14. The result revealed a significant $(\mathrm{P}<0.01)$ decrease in TSP of Group $3(5.99 \mathrm{~g} / \mathrm{dl})$ than that of Group 1 (6.68 g/dl) and Group 2 (6.66 $\mathrm{g} / \mathrm{dl}$ ). There was gradual decrease in the value of albumin from Group 1 to Group 3.

The statistical analysis of the values showed a significant $(\mathrm{P}<0.01)$ decrease in albumin content of Group 3 than Group 1 and Group 2. The changes between Group 1 and Group 2 were non-significant. The changes in globulin values of the three groups did not show a definite trend and the changes were nonsignificant. The SA: SG ratio showed a decreasing trend from Group 1 to Group 3. The analysis of variance indicated that the SA : SG ratio of Group 3 (0.86) was significantly $(\mathrm{P}<0.01)$ lower than Group 1 (1.08) and Group 2 (1.04). The result of serum enzyme activity is presented in Table 13 and the statistical analysis of the result is presented in Table 14. There was a sharp increase in the alkaline phosphatase activity of Group 3 (158.14 IU/L) than Group 1 (132.36 IU/L) and Group 2 (134.72 IU/L) and the increase in the value of Group 3 was significant $(\mathrm{P}<0.01)$ than both Group 1 and Group 2.

The result showed that Group 3 (66.11 IU/L) had significantly $(\mathrm{P}<0.01)$ higher activity of AST than Group 1 and Group 2. There was slight decrease in the activity of AST in Group 2 (60.89 IU/L) than Group 1 (61.22 IU/L) but the variation was statistically nonsignificant. The result of ALT showed that Group 3 (33.19 IU/L) had higher ALT activity than Group 1 (31.38 IU/L) and Group $2(31.94 \mathrm{IU} / \mathrm{L})$ but the changes within groups were non-significant.

\section{Haemato- biochemical study}

\section{Haematological study}

The gastrointestinal nematode infections are generally known to cause serious impact on the major haematological parameters like $\mathrm{Hb}$ concentration, PCV and TEC resulting in anaemia. In the present investigation, it was evident that the goats having EPG level higher than 1200 showed significantly lower level of $\mathrm{Hb}, \mathrm{PCV}$ and TEC. This result was corroborated with the observation of Borah (1982), Siddiqua et al., (1990), Mottelib et al., (1993), Nguyen et al., (1998) and Nsoso et 
al., (2001) in natural infection with GI nematodes. Similar observation was also reported by Rahman and Collins (1990), Sharma et al., (2000), Fakae et al., (2004) in experimental basis.

The erythrocytopenia and anaemia as observed in the present study might be due to direct blood sucking activity of some of the nematodes in addition to causing leakage of blood from the site of attachment resulting in decrease in TEC and PCV. Marked blood loss resulting as haemorrhagic anaemia due to Haemonchosis was also reported by Chakrabarti (1994). Moreover, some nematodes might have cause excessive loss of plasma protein into the GI tract causing mild nutritional anaemia. Trichostrongylus infection causes anaemia due to impaired erythropoiesis reducing the life span of erythrocytes. In the present study TLC and DLC values did not showed any significant changes. However, Siddiqua et al., (1990) and Mottelib et al., (1993) reported an increase in these values. Under natural condition repeated exposure to nematode infection in the goat might have failed to stimulate the immune system as a result leucocytosis was not marked in the present study.

\section{Serum biochemical study}

The hypoproteinaemia with decreased level of TSP and serum albumin is an important consequent of gastrointestinal parasitism associated with protein loosing enteropathy. The serum albumin level showed a significant decrease with high level of EPG in Black Bengal goat. Similar observation was also reported earlier by Siddiqua et al., (1989), Rahman and Collins (1990) and Kar et al., (2007). The protein loss in GI parasitism might be due to selective loss of albumin having smaller size and osmotic sensitivity to fluid movement. Hypoalbuminaemia in the present study obviously has been aggravated by increased catabolism of albumin and protein malabsorption through the damaged intestinal mucosa (Tanwar and Mishra, 2001). Serum globulin did not reveal any significant change as reported earlier by Rahman and Collins (1990). On the contrary Ahmad et al., (1990), Chakraborty and Lodh (1994) and Kar et al., (2007) recorded increased level of serum globulin which might be due to the severity of the infection. As a result, serum albumin and serum globulin ratio also showed a corresponding decrease as observed by Ahmad et al., (1990).

The activities of serum AP and AST were elevated in the goats with high level of EPG $(>1200)$. The elevated level of these enzymes is considered as good indicator of hepatic damage (Kaneko et al., 1997). However, elevated level of these enzymes has also been reported in GI nematode infection (Chakraborty and Lodh, 1994 and Sharma et al., 2001) and also in heavy infection with Monieziosis (Kar et al., 2007). The increased level of AST activity might be associated with damage to the intestinal mucosa by blood sucking parasites and also by severe blood loss. It might also be due to the immature stages of Fasciola sp. which damage the liver tissue. Moreover, toxic metabolites of the parasites and from the tissue damage caused by the parasites might be absorbed and detoxified in the liver as liver is the detoxifying organ resulting in increased activity of these enzymes.

The haemoglobin liberated due to breakdown of $\mathrm{RBC}$, as evident from the result might be partly taken up, catabolized in the spleen with release of bilirubin in the blood. This excess bilirubin was utilized by liver resulting in increased activities of these marker enzymes. The increased serum bilirubin level was associated with elevated alkaline phosphatase activity (Kaneko et al., 1997). 
Table.1 Analysis of variance of haematological values of Black Bengal goat in different level of EPG

\begin{tabular}{|c|c|c|c|c|c|}
\hline $\begin{array}{l}\text { Haematological } \\
\text { parameters }\end{array}$ & Source & df & $\begin{array}{l}\text { Sum of } \\
\text { Squares }\end{array}$ & $\begin{array}{l}\text { Mean } \\
\text { Square }\end{array}$ & $\mathbf{F}$ \\
\hline \multirow[t]{3}{*}{10} & Between groups & 2 & 11.22 & 5.61 & $11.74 * *$ \\
\hline & Within groups & 115 & 54.96 & 0.48 & \\
\hline & Total & 117 & 66.19 & & \\
\hline \multirow{3}{*}{ PCV } & Between groups & 2 & 135.9 & 67.95 & $8.39 * *$ \\
\hline & Within groups & 115 & 931.82 & 8.1 & \\
\hline & Total & 117 & 1067.73 & & \\
\hline \multirow{3}{*}{ TEC } & Between groups & 2 & 52.53 & 26.27 & $32.06 * *$ \\
\hline & Within groups & 115 & 94.22 & 0.82 & \\
\hline & Total & 117 & 146.76 & & \\
\hline \multirow{3}{*}{ TLC } & Between groups & 2 & 0.84 & 0.42 & 0.42 \\
\hline & Within groups & 115 & 114.21 & 0.99 & \\
\hline & Total & 117 & 115.04 & & \\
\hline \multirow{3}{*}{ Lympho } & Between groups & 2 & 24.54 & 12.27 & 0.77 \\
\hline & Within groups & 115 & 1823.98 & 15.86 & \\
\hline & Total & 117 & 1848.52 & & \\
\hline \multirow{3}{*}{ Neutro } & Between groups & 2 & 14.17 & 7.09 & 0.49 \\
\hline & Within groups & 115 & 1670.62 & 14.53 & \\
\hline & Total & 117 & 1684.79 & & \\
\hline \multirow{3}{*}{ Eosino } & Between groups & 2 & 0.91 & 0.46 & 0.64 \\
\hline & Within groups & 115 & 81.64 & 0.71 & \\
\hline & Total & 117 & 82.55 & & \\
\hline \multirow{3}{*}{ Baso } & Between groups & 2 & 0.25 & 0.13 & 0.75 \\
\hline & Within groups & 115 & 19.45 & 0.17 & \\
\hline & Total & 117 & 19.7 & & \\
\hline \multirow{3}{*}{ Mono } & Between groups & 2 & 0.02 & 0.01 & 0.03 \\
\hline & Within groups & 115 & 39.47 & 0.34 & \\
\hline & Total & 117 & 39.49 & & \\
\hline
\end{tabular}


Table.2 Serum biochemical values of Black Bengal goat in different level of EPG count $($ Mean \pm SEM $)$

\begin{tabular}{|c|c|c|c|}
\hline Biochemical parameters & $\begin{array}{c}\text { Group } 1 \\
(\mathrm{~N}=49)\end{array}$ & $\begin{array}{c}\text { Group } 2 \\
(\mathrm{~N}=58)\end{array}$ & $\begin{array}{r}\text { Group } 3 \\
(\mathrm{~N}=11)\end{array}$ \\
\hline Total Protein (g/dl) & $6.68 \pm 0.07^{\mathrm{a}}$ & $69.66 \pm 0.06^{a}$ & $5.99 \pm 0.08^{b}$ \\
\hline Serum Albumin (g/dl) & $3.46 \pm 0.03^{\mathrm{a}}$ & $3.39 \pm 0.03^{a}$ & $2.76 \pm 0.02^{b}$ \\
\hline Serum Globulin (g/dl) & $3.23 \pm 0.05$ & $3.27 \pm 0.04$ & $3.23 \pm 0.07$ \\
\hline SA:SG ratio & $1.08 \pm 0.02^{\mathrm{a}}$ & $1.04 \pm 0.01^{\mathrm{a}}$ & $0.86 \pm 0.01^{b}$ \\
\hline $\begin{array}{l}\text { Alkaline Phosphatase } \\
\text { (IU/L) }\end{array}$ & $132.36 \pm 1.37^{\mathrm{a}}$ & $134.72 \pm 1.22^{a}$ & $158.14 \pm 5.17^{b}$ \\
\hline AST (IU/L) & $61.22 \pm 0.64^{a}$ & $60.89 \pm 0.56^{a}$ & $66.11 \pm 2.16^{b}$ \\
\hline $\operatorname{ALT}(\mathbf{I U} / \mathbf{L})$ & $31.38 \pm 0.47$ & $31.94 \pm 0.43$ & $33.19 \pm 0.69$ \\
\hline
\end{tabular}

Values bearing same or no superscript within a row do not differ significantly $(\mathrm{P}<0.01)$

Table.3 Analysis of variance of serum biochemical values of Black Bengal goat in different level of EPG count

\begin{tabular}{|c|c|c|c|c|c|}
\hline $\begin{array}{c}\text { Serum } \\
\text { biochemical } \\
\text { parameters }\end{array}$ & Source & df & $\begin{array}{l}\text { Sum of } \\
\text { Squares }\end{array}$ & Mean Square & $\mathbf{F}$ \\
\hline \multirow{3}{*}{ TSP } & Between groups & 2 & 4.59 & 2.30 & $11.04 * *$ \\
\hline & Within groups & 115 & 23.91 & 0.21 & \\
\hline & Total & 117 & 28.50 & & \\
\hline \multirow{3}{*}{ SA } & Between groups & 2 & 4.43 & 2.22 & $59.43 * *$ \\
\hline & Within groups & 115 & 4.29 & 0.04 & \\
\hline & Total & 117 & 8.72 & & \\
\hline \multirow{3}{*}{ SG } & Between groups & 2 & 0.06 & 0.03 & 0.28 \\
\hline & Within groups & 115 & 11.66 & 0.10 & \\
\hline & Total & 117 & 11.71 & & \\
\hline \multirow{3}{*}{ SA: SG } & Between groups & 2 & 0.46 & 0.23 & $20.19 * *$ \\
\hline & Within groups & 115 & 1.31 & 0.01 & \\
\hline & Total & 117 & 1.78 & & \\
\hline \multirow{3}{*}{ AP } & Between groups & 2 & 6136.52 & 3068.26 & $28.75^{* *}$ \\
\hline & Within groups & 115 & 12272.76 & 106.72 & \\
\hline & Total & 117 & 18409.28 & & \\
\hline \multirow{3}{*}{ AST } & Between groups & 2 & 259.15 & 129.57 & $5.99 * *$ \\
\hline & Within groups & 115 & 2487.08 & 21.63 & \\
\hline & Total & 117 & 2746.22 & & \\
\hline \multirow{3}{*}{ ALT } & Between groups & 2 & 30.95 & 15.48 & 1.49 \\
\hline & Within groups & 115 & 1193.38 & 10.38 & \\
\hline & Total & 117 & 1224.33 & & \\
\hline
\end{tabular}


There was no significant change in the activity of serum ALT which was corroborated with the findings of Ahmed and Ansari (1989). However, Chakraborty and Lodh (1994), Sharma et al., (2001) and Kar et al., (2007) reported significant increase in the ALT value which might be associated with severity of infection. The does of base stock having EPG count more than 1200 (Group 3) showed anaemia and erythrocytopenia with significant decrease in PCV and TEC and hypoproteinaemia with reduction in TSP and SA. The Group 3 animals also showed significant increase in alkaline phosphatase and AST activity. Though the affected goats do not show clinical illness but EPG count more than 1200 can lead to anaemia, erythrocytopenia, hypoproteinaemia and increased activity of serum AST and alkaline phosphatase enzymes.

So it may be suggested that apart from other selection criteria like growth, biometry, reproductive performance of ancestors, selection of GI nematode resistant Black Bengal goats on the basis of faecal egg count of nematodes and its indicator trait i.e. PCV may be considered as an important selection tool for improvement of Black Bengal goat in the farmers' house towards economic goat rearing and hence this breeding practice has a potential for improving the livelihood of the poor farmers.

\section{References}

Ahmad, A.; Anwar ul Hassan, C.; Anwar ul Haq, A.; Majeed, M.A. (1990). Serum proteinogram of lambs in experimentally induced Haemonchus contortus infection. Veterinarski Arhiv (Yugoslavia). 60(4): 195-200.

Ahmed, M. and Ansari, J.A. (1989). Effect of haemonchosis on haematology and nonspecific phosphomonoesterase activities in sheep and goats. Helminthologia. 26(4): 295-302.
Borah, D.J., Baruah, P.K., Gogoi, A.R. and Roychoudhury, G.K. (1982). Studies on some haematological and biochemical changes in goats infected with Strongyloides papillosus. J. Res. Assam Agricultural University. 3(1): 24-27.

Chakraborty, D. and Lodh, C., 1994. Blood biochemical profiles in Fasciola, Haemonchus and Dictyocaulus species infection in goat - a comparative study. Ind. Vet. J., 71: 286-288.

Coles, G.C., Bauer, C., Borgsteede, F.H.M., Geerb, S., Klei, T.R., Taylor, M.A. and Walter, P.J. (1992). World Association for the advancement of Veterinary Parasitology (WAAVP) methods for the detection of antihelmintic resistance in nematodes of Veterinary importance. Vet. Parasitol. 44(1-2): 35 -44.

Dhara, K. C. Bandopadhyay P.K and Goswami A. (2011) Influence of Gastro-Intestinal Parasites on Productive and Reproductive performances of Black Bengal Goat under Field condition. International Journal of Science and Nature. 2(3): 638- 647.

Dumas, B.T., Arends, R.L. and Pinto, P.V.C. (1971). Standard methods of Clinical Chemistry. 7: 175-189.

Fakae, B.B., Musongong, G.A., Chiejina, S.N., Behuke, J.M., Ngongeh, L.A. and Wakelin, D. (2004). Variability in the resistance of the Nigerian West African dwarf goat to abbreviated escalating trickle and challenge infections with Haemonchus contortus. Vet. Parasitol. 122(1): 51-65.

Hawlader, M.M.R., Mahbub-e-Elahi, A.T.M., Habib, S. and Bhuyan, M.J.U. (2002). Gastro-intestinal nematode infestations in the Black Bengal goats of Sirajgong district of Bangladesh. J. Biol. Sci. 2(8): 556-557.

Kar, I., Bhowmik, M.K., Ghosh, J.D., Mukhopadhyay, S.K. and Datta, S. (2007). Prevalence and pathology of monieziosis in goats of West Bengal. Indian J. Vet. Pathol. 31(2): 183-184.

Kind, P.R.N. and King, E.J. (1954). Estimation of plasma phosphatase by determination 
of hydrolysed phenol with amino antipyrins. J. Clin. Path. 7: 322-326.

Kaneko, J.J.; Harvey, J.W., Bruss, M.L. Clinica biochemistry of domestic animals. San Diego:Academic, 1997. 932p.

Mottelib, A.A., Ammar, A.M. and Magzoub, M. (1993). The haemogram of enteritis in kids at El-Gassim. Australian J. Vet. Med. 28(56): 255-263.

Nguyen, T.K.L., Phan, D.L., Nguyen, K.Q. and Nguyen, V.Q. (1998). Some remarks on the macroscopic lesions and blood index of goats infected with digestive system helminths. Khoa Hoe Ky Thuat Thu Y. 5(3): 94-98.

Nsoso, S.J., Machets, J.B., Molatole, M., Ndebele, R.T., Lebani, N.N., Chabo, R.G., Kalake, A.M., Jacvna, L., Segadimo, B.W. and Mine, O.M. (2001). The impact of traditional management on seasonal internal parasite burdens and productivity of indigenous Tswana goats in southern Botswana. Onderstepoort J. Vet. Res. 68(2): 101-104.

Rahman, W. A. Collins, G. H. (1990). Changes in live weight gain, blood constituents and worm egg output in goats artificially infected with a sheep-derived strain of Haemonchus contortus. British Vet. J. 146(6): 543-550.

Reinhold, J.G. (1953). In. Standard Methods of Clinical Chemistry, (Ed. M. Reiner), Academic Press, New York and London. pp-88.

Reitman, S. and Frankel, S. (1957). A colorimetric method for the determination of serum glutamic oxaloacetic and glutamic pyruvic transaminases. American J. Clin. Pathol. 28: 55-63.

Rout, P.K. and Chauhan, K.K. (2004). Genetics of disease resistance in goats. Proceedings of Seminar on "Goat Genome". Central Institute for Research on Goats, Makhdoom, Mathura, UP, India. pp-6474.

Schalm, O.W.; Jain, N.C. and Carroll, E.J. (1986). Veterinary Haematology. $\quad 4^{\text {th }}$ Edn. Lea and Febiger, Philadelphia.

Sharma, D.K., Chauhan, P.P.S. Agrawal, R.D. (2000). Haematological changes in experimental haemonchosis in Barbari goats. J. Anim. Sci. 70(4): 353-355.

Sharma, D.K., Chauhan, P.P.S.and Agrawal, R.D. (2001). Changes in the levels of serum enzymes and total protein during experimental haemonchosis in Barbari goats. Small Ruminant Res. 42(2): 119123.

Siddiqua, A., Mannan, M.A. and Hussain, M.A. (1989). Some biochemical studies in the blood of goats naturally infected with intestinal parasites. Indian Vet. J. 66(5): 502-504.

Siddiqua, A., Mannan, M.A. and Hussain, M.A. (1990). Haematological studies in Black Bengal goats naturally infected with intestinal parasites. Indian J. Anim. Health. 29(1): 77-79.

Snedecor, G.W., and Cochran, W.G. (1994). Statistical Methods. 8th Edn. Oxford and IBH Publishing Co. Pvt. Ltd., New Delhi.

Soulsby, E.J.L. (1982). Helminth, arthropods and Protozoa of Domesticated Animals. pp- 136-346, 763-778. Bailliere Tindall, London, Great Britain.

Tanwar, R.K. and S. Mishra, 2001. ClinicoHaematoBiochemical studies on intestinal helminthiasis in poultry. Vet. Practitioner, 2: 137-140.

\section{How to cite this article:}

Dhara, K. C., N. Ray, S. S. Kesh, P. K. Bandopadhyay, S. Batabyal and Goswami, A. 2020. Haemato-Biochemical Profile of Black Bengal Goat on Different Gastro-Intestinal Parasitic Load. Int.J.Curr.Microbiol.App.Sci. 9(04): 1601-1610.

doi: https://doi.org/10.20546/ijcmas.2020.904.187 